U. S. GECLOGICAL SURVEY Field Library

Albuquerque, New Mexico

\title{
Radioactivity Reconnaissance
}

of Part of North-Central

Clear Creek County,

Front Range, Colorado

By J. D. Wells and J. E. Harrison

Trace Elements Investigations Report 305

UNITED STATES DEPARTMENT OF THE INTERIOR GEOLOGICAL SURVEY 
Geology and Mineralogy

This document consists of 21 pages. plus 2 figures.

Series A

UNHTED STATES DEPARTMENT OF THE INTERIOR

GEOLOGICAL SURVEY

RADIOACTIVITY RECONNAISSANCE OF PART OF NORTH-CENTRAL

CLEAR CREEK COUNTY。 FRONT RANGE, COLORADO*

By

John $D_{0}$ Wells and Jack E. Harrison

July 1953

Trace Elements Investigations Report 305

This preliminary report is distributed without editorial and technical review for conformity with official standards and nomenclature. It is not for public inspection or quotation.

This report concerns work done on behalf of the Division of Raw Materials of the $U_{\circ} S_{\circ}$ Atomic Energy Commission。 
Distribution (Series A) No. of copies

American Cyanamid Company, Winchester ............ 1

Argonne National Laboratory ................. 1

Atomic Energy Commission, Washington . . . . . . . . . 2

Battelle Memorial Institute, Columbus ............... 1

Carbide and Carbon Chemicals Company, Y-12 Area ........ 1

Division of Raw Materials, Albuquerque ............ 1

Division of Raw Materials, Butte ................ 1

Division of Raw Materials, Denver .............. 1

Division of Raw Materials, Douglas .............. 1

Division of Raw Materials, Grants ............... 1

Division of Raw Materials, Hot Springs . . . . . . . . . . 1

Division of Raw Materials, Ishpeming .............. 1

Division of Raw Materials, New York ............ 6

Diwision of Raw Materials, Phoenix ............. 1

Division of Raw Materials, Richfield .............. 1

Division of Raw Materials, Salt Lake City . . . . . . . . . 1

Division of Raw Materials, Washington ............ 3

Dow Chemical Company, Pittsburg ............. 1

Exploration Division, Grand Junction Operations Office . . . . . . . 1

Grand Junction Operations Office . . . . . . . . . . . 1

Technical Information Service, Oak Ridge . . . . . . . . . 6

Tennessee Valley Authority, Wilson Dam . . . . . . . . . 1

U. S. Geological Survey:

Alaskan Geology Branch, Washington ............... 1

Fuels Branch, Washington. . . . . . . . . . . . . . 1

Geochemistry and Petrology Branch, Washington .......... 1

Geophysics Branch, Washington ............... 1

Mineral Deposits Branch, Washington ............. 3

E。 Hailey, Menlo Park ................. 1

K。 L. Buck, Denver ..................... 2

J. R. Cooper Denver .................... 1

N. M. Denson, Denver ................... 1

C. E. Dutton Madison .......................... 1

R. P. Fischer, Grand Junction ................. 1

$L_{\text {s }} \mathrm{S}_{\text {. Gardner }}$ Albuquerque .................. 1

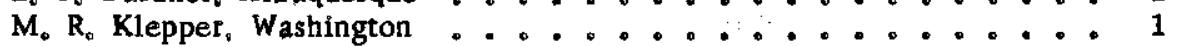

A. $H_{0}$ Koschmann, Denver ................. 1

$R_{\circ}$ A. Laurence, Knoxville ................... 1

D. $M_{\circ}$ Lemmon, Washington ................. 1

I. D. Love Laramie

R. G. Petersen, Plant City ................. 1

R. I. Roberts, Salt Lake City .................. 1

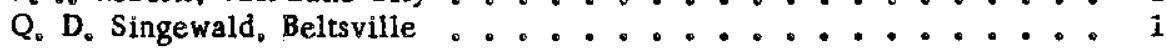

$\mathbb{J}_{0}$ F。 Smith $\mathrm{Jr}_{0}$. Denver . . ................ 1

R. W. Swanson, Spokane ............................. 1

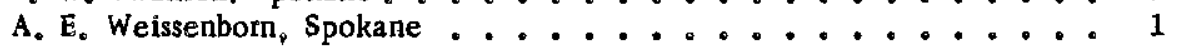

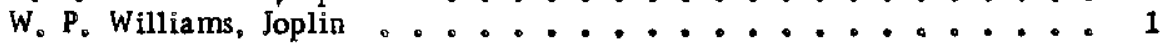

TEPCO $_{0}$ Denver ...................... 2

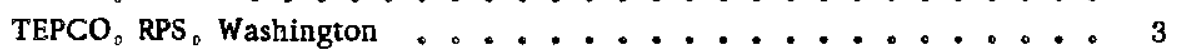

(Including master) 


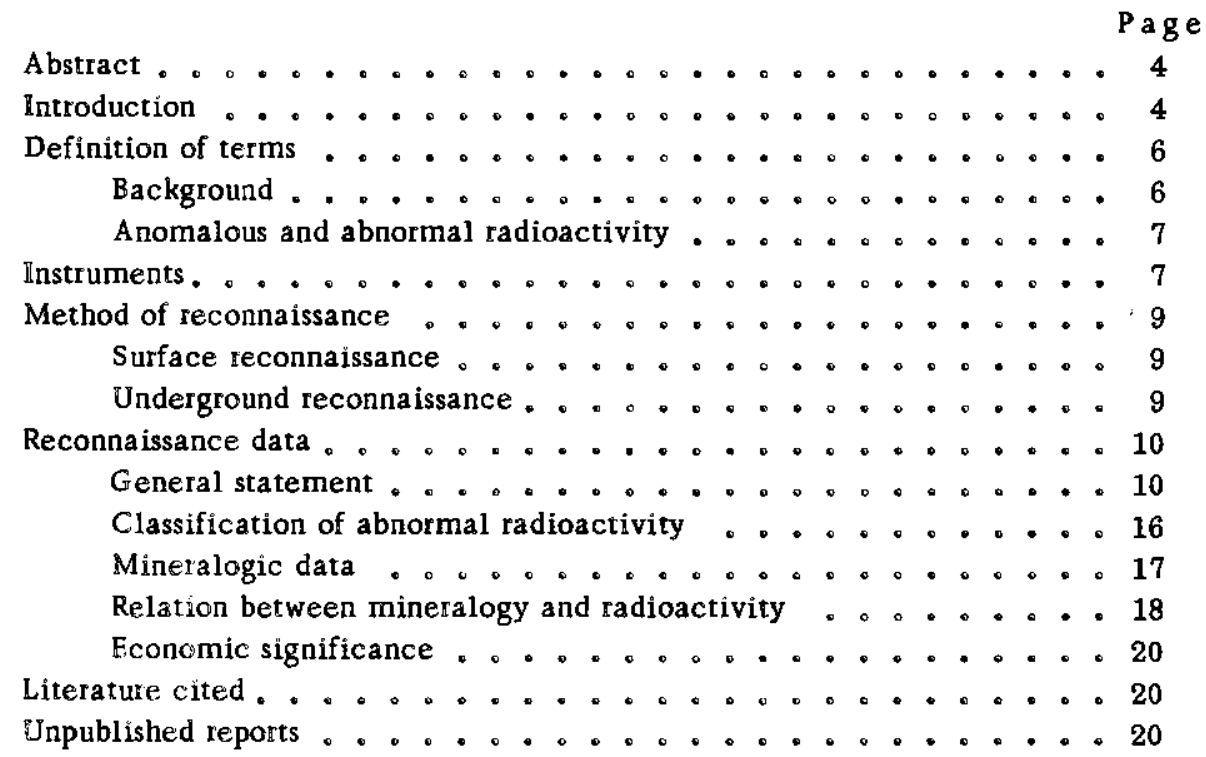

\section{ILLUS TRATIONS}

Figure 1. Index map of central Colorado showing area covered by reconnaissance 。.................. 5

2. Map of north-central Clear Creek County, Colorado, showing radioactivity of localities examined ......... In envelope

3. Map of part of north-central Clear Creek County. Colorado. showing distribution of vein types .......... In envelope

\section{TABLES}

Table 1. Radioactivity and mineralogic data for localities of high, moderate, or low abnormal radioactivity . . . . . . 11

2. Relation of significant abnormal radioactivity and vein mineralogy ................. 18

3. Relation of significant abnormal radioactivity to mineral zones .................. 19 


\section{RADIOACTIVITY RECONNAISSANCE OF PART OF NORTH-CENTRAL \\ CLEAR CREEK COUNTY。FRONT RANGE。COLORADO}

by John $D_{0}$. Wells and Jack $E_{\text {. }}$ Harrison

\section{ABSTRACT}

During the field seasons of 1951 and 1952, 334 localities in north-central Clear Creek County, Colo. . were examined for abnormal radioactivity. Seven of the localities contain sufficient uranium to warrant some physical exploration.

Within the investigated region the highest proportion of occurrences of significant abnormal radioactivity is in veins that contain chalcopyrite. Also the highest grade samples are from chalcopyrite-bearing veins, Any locality or zone containing pyritic gold veins is unfavorable for finding a uranium deposit.

\section{INTRODUCTION}

A radioactivity reconnaissance of north-central Clear Creek County was made during 1951 and 1952 by the writers as a part of the $U_{0} S_{*}$ Geological Survey's investigations of the uranium deposits in the Central City -Idaho Springs region (fig. 1). This work was done on behalf of the Division of Raw Materials of the U. S. Aromic Energy Commission. Previous work in this region was done by Smith and Baker (1951, p. 5-10) of the U. S. A tomic Energy Commission. Because their report is a tabulation of radioactivity investigations in the area covered by figure 2 , it includes the results of the earlier investigation. A summary of the resuits was given earlier (Sims, Harrison, and Moore, 1953).

The purpose of the reconnaissance was to determine the distribution and the economic importance of the radioactive occurrences of this region. The methods, as well as the results, of the investigation are given in this report, because the reconnaissance methods used during this investigation might be useful elsewhere.

Most of the new information presented in this report was gathered by Wells: Harrison is largely responsible for the information from the Freeland-Lamartine area. F. B. Moore gave the writers additional information on the Fall River area. 


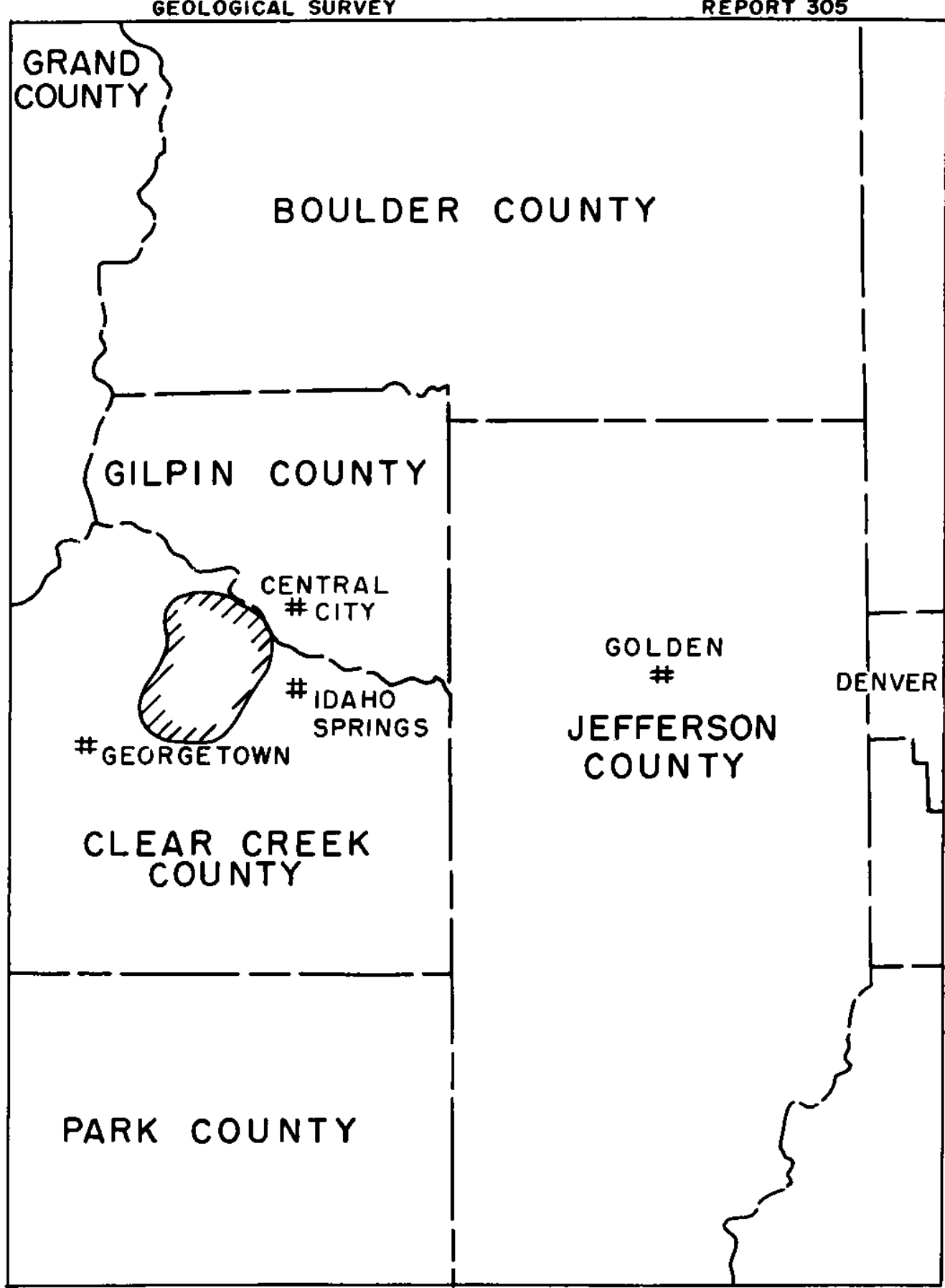

FIGURE I-INDEX MAP OF CENTRAL COLORADO, SHOWING AREA COVERED BY RECONNAISSANCE

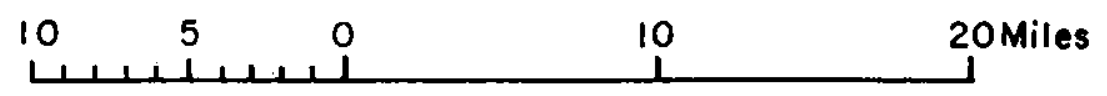




\title{
DEFINITION OF TERMS
}

\author{
Ba ckground
}

Background as defined by Korff (1946, p. 23-24) is the instrument reading, at that particular time and place, caused by internal contamination of the counter. cosmic radiation, and the natural radioactivity of the surroundings. In precise laboratory determinations of radioactivity, the sum effect of these three factors is carefully determined. In the type of field reconnaissance done by the writers, the field measurements of radioactivity are used only to locate favorable areas to sample; therefore. the limits of error are much broader. For field measurements of radioactivity, the factor of variations in internal contamination can be ignored.

Cosmic radiation increases with altitude, therefore, the factor of variations of cosmic radiation was eliminated by establishing background at the approximate elevation of the area to be traversed. No attempt is made in this report to compare widely separated localities on the basis of field measurements of radioactivity.

The measurement of radioactivity at a given locality includes a geometric factor as well as a geologic factor Other factors being equal, more radiation from a given rock type will be recorded in the bottom of a narrow canyon than from the same rock type on the top of a hill. The quantity of radiation reaching the instrument is increased through the proximity of a greater volume of radioactive material. The geometric factor can be ignored for all practical purposes of surface reconnaissance by recording background almost anywhere on the surface of the ground except at the bottom of a canyon. In the area of the Front Range covered by this report the radioactivity of the various rocks varies widely. In genera1. the radioactivity of the schistose rocks, mafic rocks, granite gneisses, and Boulder Creek granite is low relative to the intrusive rocks of Tertiary age and to the Silver Plume granite of pre-Cambrian age. From the analyses of several samples, Phair (1952) found that most of the Tertiary intrusive rocks have less than 0.02 percent equivalent uranium. Numerous scintillation counter readings on Silver Plume granite indicate that this granite has a nearly constant level of radioactivity over a wide area. A sample of this granite, considered to be representative contained 0.006 percent 
equivalent uranium. The radioactivity of vein material also is variable, for some veins contain no radioactive minerals and others contain pitchblende or other uranium minerals. In order to standardize the effect of the different rock types on the background, the background was established whenever possible over rocks known to be low in natural radioactivity. The rocks containing the lowest natural radioactivity were chosen as the standard because this reconnaissance was concerned with the measurement of the radioactivity of veins in a range below the natural radioactivity of the Tertiary dikes and Silver Plume granite. The term background is used in this report to mean the average radiation recorded at a given place and time over rock materials known to be low in natural sadioactivity.

Anomalous and abnormal radioactivity

Any fluctuation from the general level of background is defined for this report as anomalous radioactivity. As an increase in radioactivity over the background can result from either radioactive vein material or unusually radioactive rocks, it is essential to distinguish the cause of the anomaly. The anomaly recorded from the highly radioactive country rocks has no relationship to possible uranium deposits in Tertiary veins.

Abnormal Iadioactivity is defined for this teport as anomalous radioactivity caused by a concentration of radioactive material in Tertiary veins.

\section{INSTRUMENTS}

A portable scintillation detector and a portable survey meter with a 6 -inch gamma-beta Geiger tube were used for the reconnaissance. Although both of these instruments measure radioactivity, the characteristics of each instrument are such that one supplements the other.

The portable scintillation detector measures gamma radiation only. Gamma radiation is more penetrating ("harder ${ }^{\circ 9}$ ) than beta zadiation: therefore, gamma radiation can be detected through greater thicknesses of rock materials and at greater distances from the source than beta radiation. In addition. a scintillation counter has a very high efficiency for the detection of gamma radiation; a Geiger counter has an efficlency of about 1 percent or less for the detection of gamma tadiation (Brownell, 1950, $p_{0} 167$ ), 
but the scintillation counter has an efficiency of 20 to 25 percent for gamma rays. The larger number of impulses per unit time recorded by a scintillation counter combined with a mechanism to average the counts over several seconds results in a fairly stable dial reading A change of 10 percent in the dial

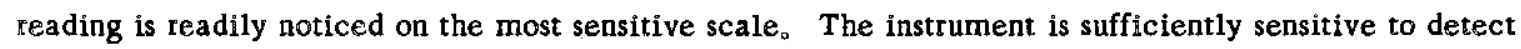
large amounts of low-grade material as well as moderately small amounts of high-grade material。A scintillation detector is well adapted for field use when the purpose is to detect changes in the amount of gamma radiation dependent upon quantity or bulk of radioactive material regardless of grade A scintillation counter was used in this reconnaissance to locate areas of anomalous radioactivity.

The portable survey meter wỉh a 6 -inch gamma-beta Geiger tube is not very sensitive to moderate amounts of radiation when the probe is held more than a foot or two away from the source. Only a small amount of radiation present in any particular area is recorded by the Geiger tube because of its low efficiency. Also the dial reading is inherently less stable than that of a scintillation counter. A 10-percent change in the reading on the most sensitive scale is very difficult to detect with confidence under field conditions. The survey metet supplements the scintillation detector because it is sensitive to a small source area. A survey meter was used in this reconnaissance to isolate the specific mineral or material causing abnormal radioactiviry。

Both instruments will detect the presence of radon in a mine. Only very general statements can be made as to the quantity of gas present. In the presence of radon, both instruments will show a gradual increase in amount of radiation recorded even though the instrument is kept stationary. Even after the instrument is brought out of the mine, a higher-than-normal reading will continue for some time 
METHOD OF RECONNAISSANCE

Surface reconnaissance

In this reconnaissance the first procedure was to determine the local background for the instruments。 The background for the scintillation counter was determined near the area to be examined so that local variations in cosmic radiation were eliminated. The background for a rate meter with a gamma-beta probe was determined by holding the probe several feet in the air to eliminate the effect of the rock material.

The area or dump to be examined was then traversed, using the scintillation counter. Traverses were made about 6 feet apart, holding the counter a few inches from the surface of the ground to obtain readings from a maximum depth ${ }_{\mathrm{v}}$ The traverses were made slowly to allow the instrument time to average the radioactive count for the material being traversed.

During this reconnaissance, abnormal radioactivity greater than twice background on the rate meter was considered significant, and the radioactive material was sampled, Abnormal radioactivity less than twlee background on either instrument is reported in this paper but the rocks causing the radioactivity were not sampled.

\section{Underground reconnaissance}

A procedure similar to that for surface reconnaissance was followed for underground reconnaissance. Underground the background appears to be slightly higher than at the surface. Background was established underground by recording the instrument reading at least 50 feet from the portal or shaft.

Traverses were made by carrying the instrument at waist height. The scintillation counter used in this reconnaissance repeatediy recorded anomalies from small areas and thin fractures. Samples of material from these anomalous areas commonly assayed as low as 0.006 percent equivalent uranium.

Traversing of mines that contain radon is impractical because the instrument becomes contaminated. Henry Faul (oral communication)。 of the Geological Survey, has reported some success in combatting this contamination by placing the probe of the instrument in a plastic or rubber bag before entering a mine containing the gas. 


\section{RECONNAISSANCE DATA}

\section{General statement}

A reconnaissance for radioactivity is useful in making a qualitative and broad quantitative estimate of the potentialities of a region for wanium production; that is, it can be used to determine the presence or absence of abnormal radioactivity. The grade of the material cannot be determined accurately, however, because the field measurements are made on non-homogeneous samples of different sizes. During this examination, any locality showing significant abnormal radioactivity was sampled, and these samples were sent to the laboratory for accurate determinations of equivalent uranium and uranium. To obtain dump samples that most nearly represent the highest-grade ore in the mine, only the material showing the highest radioactivity was sampled.

The results from more than forty assays show that most of the samples, particularly those collected from dumps, have radioactivity equivalent to more uranium than is actually present (table 1). Phair and Levine (1952, p. 14) have shown by a study of vein material from a dump that this condition of disequilibrium can be caused by acid solutions which leach uranium and leave a concentration of the radioactive disintegration products of uranium.

Equivalent uranium is used in this report as a basis for classification of the localities showing abnormal radioactivity. The assumption is made that the radioactive materials associated with Tertiary veins are in equillibrium. Because uranium is leached rapidly from material on dump surfaces (Phair and Levine, 1952). the radioactivity of a dump sample rather than the actual uranium content of that sample is probably more representative of the amount of uranium present in the fresh vein in the mine.

The apparent absence of radioactive material on a dump does not necessarily mean that no radioactive material occurs in the mine. Several dumps of inaccessible mines have been reported to show no abnormal radioactivity, but underground examinations following re-opening of the mine have revealed significant a mounts of abnormal radioactivity. 
Table 1. $\sim$ Radioactivity and mineralogic dara for localities of high, moderate, or low abnormal tadioactivity.

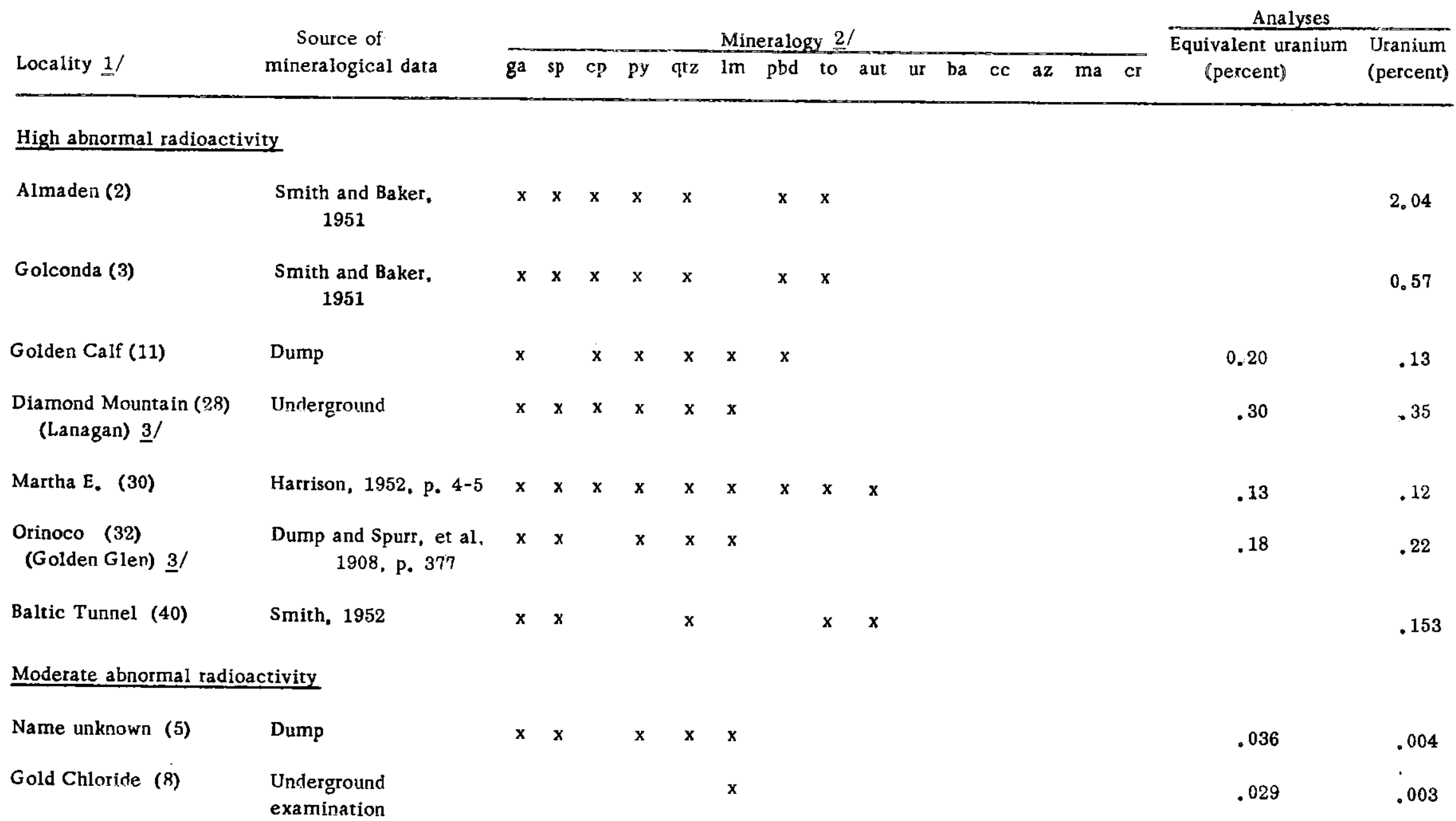

$\underline{1 /}$ Number after locality refers to number on figure 2.

2/ Explanation of abbreviations: ga-galena; sp- sphalerite; cp-chalcopyrite; py- pyrite; qtz- quartz; lm- limonite; pbd- pitchblende;

to- torbernite; aut- autunite; ur-uranophane; ba- barite; cc- chalcocite; az- azurite; ma- malachite; cr-carbonate。

3/ Name in parentheses used in earlier $U_{\text {. }} S$, Geol survey publications。 
Table 1. - Radioactivity and mineralogic data for localities of high, moderate, or low abnormal radioactivity -- Continued

\begin{tabular}{|c|c|c|c|c|c|c|c|c|c|c|c|c|c|c|c|}
\hline \multirow[b]{3}{*}{ Locality $1 /$} & \multirow{3}{*}{$\begin{array}{c}\text { Source of } \\
\text { mineralogical data }\end{array}$} & \multicolumn{5}{|c|}{$\therefore$} & \multirow{2}{*}{\multicolumn{7}{|c|}{ Mineralogy 2/ }} & \multicolumn{2}{|l|}{ Analyses } \\
\hline & & & & & & & & & & & & & & \multirow{2}{*}{$\begin{array}{l}\text { Equivalent uranium } \\
\text { (percent) }\end{array}$} & \multirow{2}{*}{$\begin{array}{r}\text { Uranium } \\
\text { (percent) }\end{array}$} \\
\hline & & ga & $\mathrm{sp}$ & cP & py & $q t z$ & $\operatorname{lm} \mathrm{pbd}$ & to aut & ur & $\mathrm{ba}$ & $\mathrm{cc}$ & $\mathbf{a z}$ & $\mathrm{ma} \quad \mathrm{cr}$ & & \\
\hline \multicolumn{16}{|c|}{ Moderate abnormal radioactivity --continued } \\
\hline \multirow{2}{*}{ Sunnyside tunnel (16) } & Underground & $\mathbf{x}$ & $\mathbf{x}$ & $\mathbf{x}$ & $\mathbf{x}$ & $\mathrm{x}$ & $\mathbf{x}$ & & & & & & & 0.043 & 0.019 \\
\hline & & & & & & & & & & & & & & .092 & .003 \\
\hline $\begin{array}{l}\text { Middle tunnel, } \\
\text { Little Johnie group (18) }\end{array}$ & $\begin{array}{l}\text { Underground } \\
\end{array}$ & $\mathbf{x}$ & $\mathbf{x}$ & $\mathrm{x}$ & $x$ & $x$ & $x$ & & & & & & & .037 & .033 \\
\hline Poor Man (20) & Dump & & & & & & $\mathbf{x}$ & & & & & & & .028 & .023 \\
\hline Brazil (21) & Dump & $x$ & $\mathbf{x}$ & $\mathrm{x}$ & $x$ & $\mathrm{x}$ & $\mathbf{x}$ & & & $\mathrm{x}$ & & & & .040 & .038 \\
\hline Crazy Girl (24) & Underground & $\mathbf{x}$ & $\mathrm{x}$ & $\mathrm{x}$ & $x$ & $\mathbf{x}$ & $\mathbf{x}$ & & & & $\mathrm{x}$ & $x$ & $\mathrm{x}$ & .033 & .026 \\
\hline Ariadne (25) & Dump & & & & & $\mathrm{x}$ & & $x$ & $x$ & & & & & .039 & .032 \\
\hline Belle Creole (27) & Underground & $\mathbf{x}$ & $x$ & $x$ & $x$ & $\mathbf{x}$ & $\mathrm{x}$ & & & & & & & .037 & .033 \\
\hline Gomer (29) & Dump & $\mathbf{x}$ & $x$ & $x$ & $\mathbf{x}$ & $\mathbf{x}$ & $\mathbf{x}$ & & & & & & & .068 & .072 \\
\hline $\begin{array}{l}\text { Silver Ring (33) } \\
\text { (Silverine) }\end{array}$ & $\begin{array}{l}\text { Dump and Spurr, et al. } \\
1908 \text {, p. } 375-376\end{array}$ & & $\mathrm{x}$ & & & $\mathrm{x}$ & $x$ & & & & & & & .028 & .028 \\
\hline Muscovite (35) & $\begin{array}{l}\text { Dump and Spurr, et al, } \\
1908, \text { p. } 375-376\end{array}$ & & $\mathrm{x}$ & & & $\mathrm{x}$ & $\mathrm{x}$ & $x$ & & & & & & .047 & .046 \\
\hline
\end{tabular}


Table 1. - -Radioactivity and mineralogic data for localities of high。 moderate, or low abnormal radioactivity。--Continued

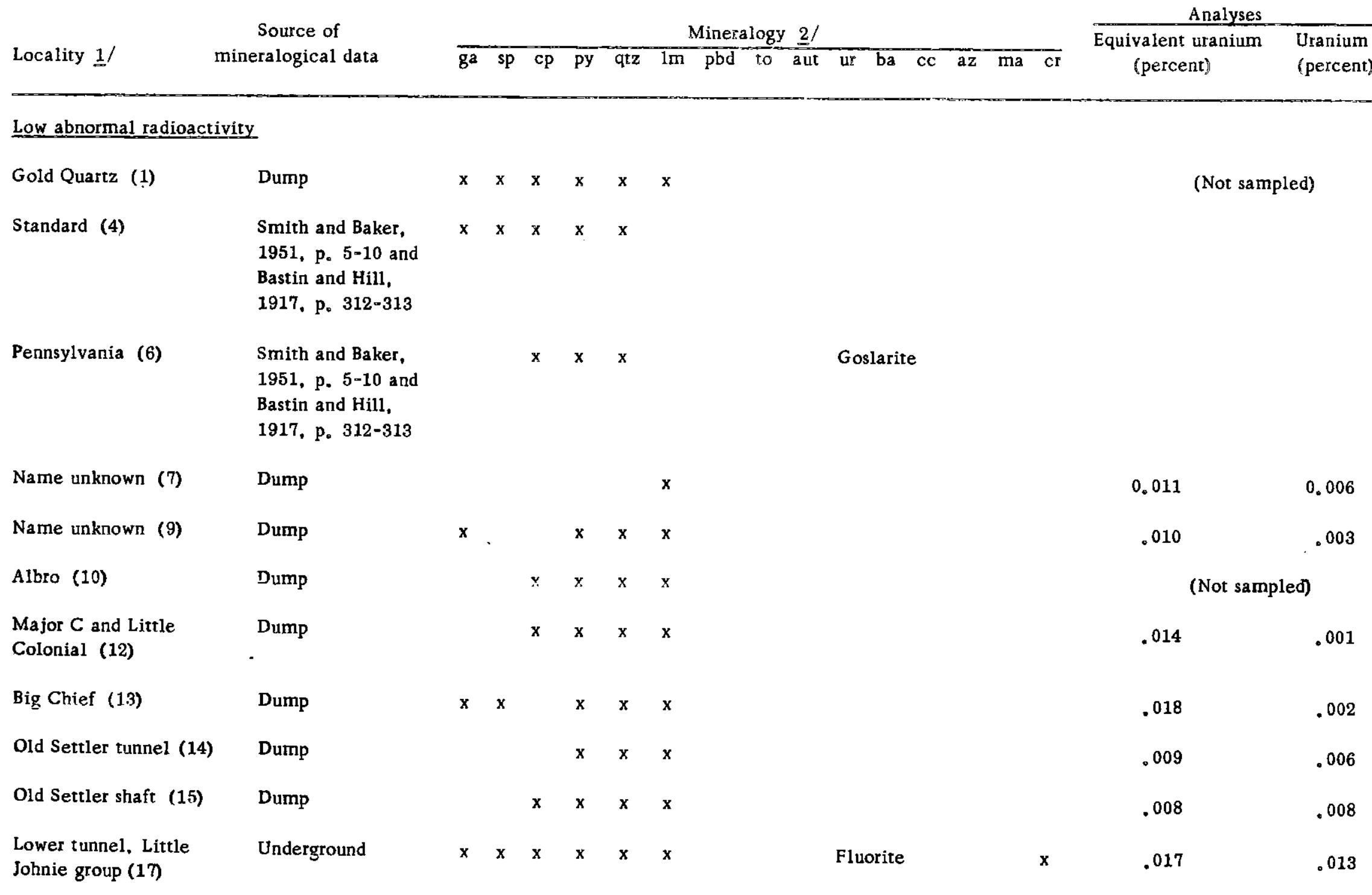


Table 1. - - Radioactivity and mineralogic data for localities of high, moderate, or low abnormal radioactivity. - Continued

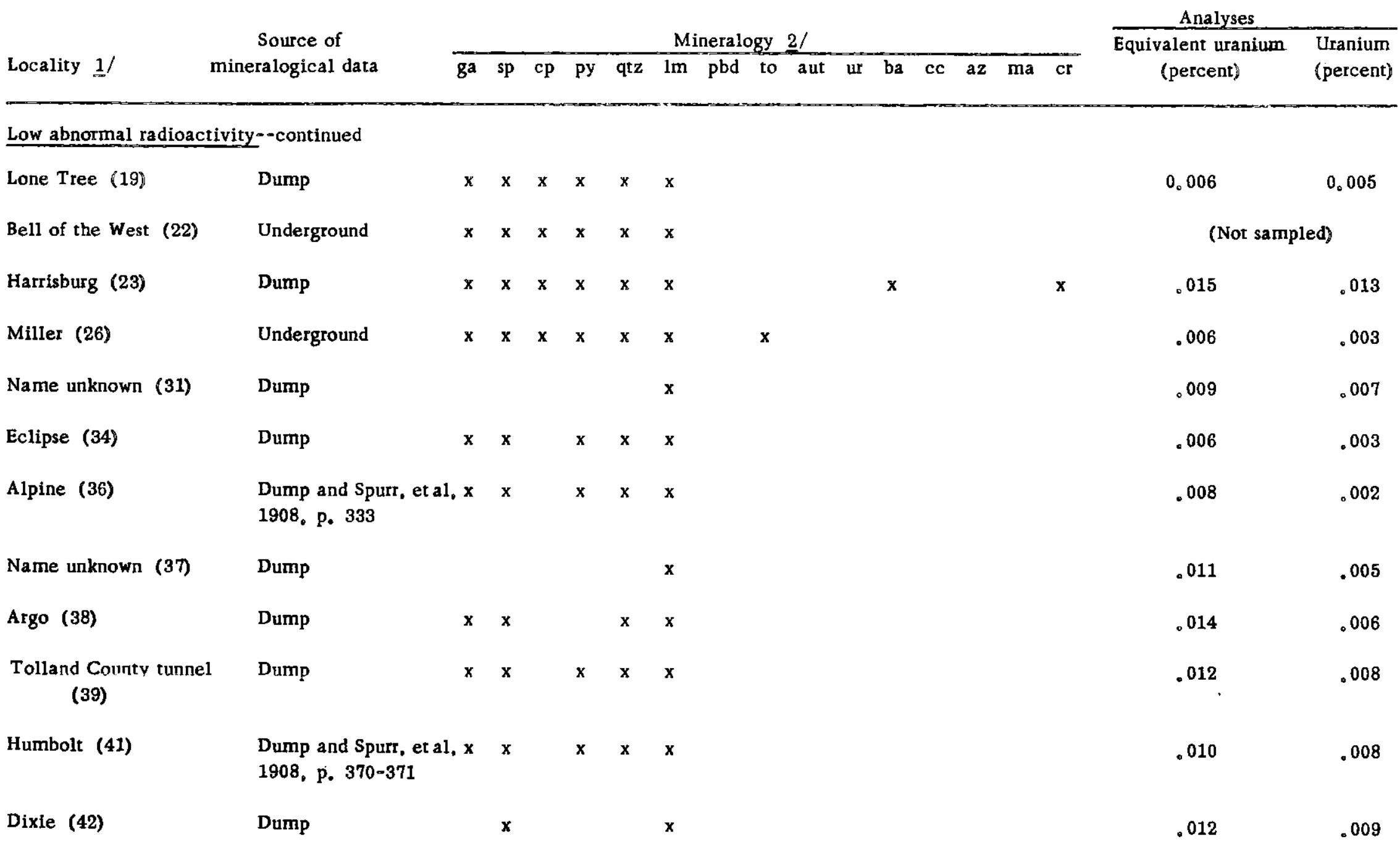


Table 1.--Radioactivity and mineralogic data for localities of high, moderate ${ }_{\circ}$ or low abnormal radioactivity。 $-\cdots$ Continued

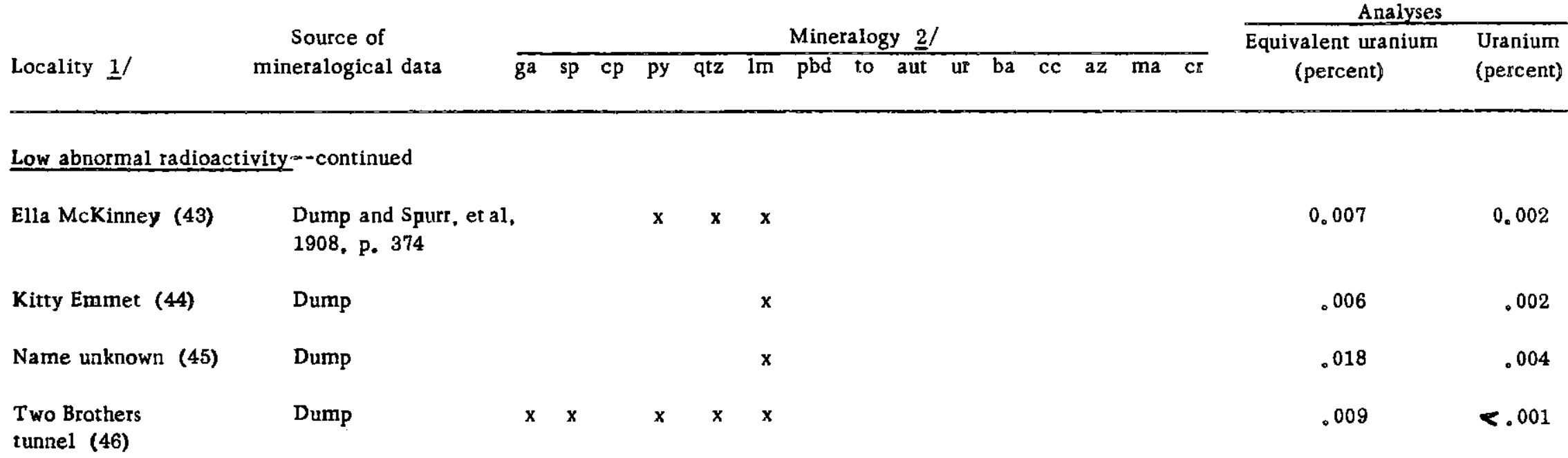




\section{Classification of abnormal radioactivity}

For the purpose of this report, the intensity of the abnormal radioactivity is classified as follows: 1) slight abnormal radioactivity is radioactivity greater than background but less than twice background, 2) low abnormal radioactivity is in the range between 0.005 percent and 0.020 percent equivalent uranium. 3) moderate abnormal radioactivity is in the range between 0.021 percent and 0.099 percent equivalent uranium, and 4) high abnormal radioactivity is 0.10 percent or more equivalent uranium, Localities where abnormal radioactivity was noted are shown on figure 2 。

The classification is based upon field instrument readings and laboratory determinations of equivalent uranium. This is necessary because samples were not collected from localities with abnormal radioactivity less than twice background. Twice background, as determined by the authors is approximately 0.005 percent equivalent uranium. The category of slight abnormal radioactivity used in this report can be inferred to mean radioactivity that is generally less than 0,005 percent equivalent uranium. As this amount of radioactivity cannot be evaluated as yet, information on localities containing slight abnormal radioactivity is not given in table 1 .

As has been stated, the lower limit of the low abnormal radioactivity is approximately equal to the equivalent uranium content of a sample showing twice background. The upper limit was placed at 0.020 percent equivalent uranium because all of the pre-Cambrian rocks and most of the Tertiary intrusive rocks contain less than 0.020 percent equivalent uranium. This range of abnormal radioactivity overlaps the range of anomalous radioactivity of some of the country rocks. The moderate abnormal radioactivity class has more equivalent uranium than the country rocks, but less equivalent uranium than present ore-grade material which is in equilibrium. The high abnormal radioactivity class has equivalent uranium equal to or greater than that of present ore grade material which is in equilibrium. 


\section{$M$ ineralogic data}

The mineral suites identified at the localities included in this report have previously been recognized by Spurr, Garrey, and Ball (1908) and by Bastin and Hill (1917). Bastin and Hill (p。105) have shown that these mineral suites are characteristic of three vein types, and this classification is used in this report. The vein types are: 1) pyritic, predominantly pyrite and quartz with minor amounts of chalcopyrite. 2) galena-sphalerite, predominantly galena, sphalerite, pyrite, and quartz with a subordinate amount of chalcopyrite, and 3) composite veins in which type 2 crosscuts type 1.

As much of the data in this report were obtained from dumps, the detailed relationships between vein types necessary to identify the composite type of vein are unknown. The composite type of vein, therefore, cannot be discussed and is not shown on figure 3 .

Leonard (1952) suggests that in the Central City area appreciable quantities of chalcopyrite may occur in the intermediate zone between areas of predominantly pyritic type veins and areas of predominantly galena-sphalerite type veins, Leonard notes that pitchblende appears to occur principally in this intermediate zone.

The vein type occurring at each locality examined during this study is shown on figure 3. The area where veins of the pyritic type predominate has been outlined on figure 3 . The southwestern part in the vicinity of Ute Creek on figure 3 is an area where veins of the galena-sphalerite type predominate and which do not contain chalcopyrite. An approximate boundary has been drawn between the area around Freeland, in which veins of the galena-sphalerite type with chalcopyrite predominate, and the area to the southwest in which chalcopyrite is absent in the galena-sphalerite type of veins. In the northern part of the area shown on figure 3 the information is inadequate to distinguish major areas similar to those shown on the southwest part of the map area. 


\section{Relation between mineralogy and radioactivity}

In the area covered by this report, 334 localities have been checked for abnormal radioactivity, and eighty of these have abnormal radioactivity $\rightarrow-7$ have high, 12 have moderate, 27 have low, and 34 have slight abnormal radioactivity (fig。2)。 The mineralogy of all localities having significant abnormal radioactivity is shown in table 1 .

To relate the distribution of radioactive localities to vein mineralogy, two tables were prepared _/. In table 2, abnormal radioactivity is related to the mineralogy of each locality examined, In table 3 radioactivity is related to hypogene mineral zones.

From the data presented in table 2 three observations can be made:

1. The localities where pyrite was the sole ore mineral identified have a small percentage of significant abnormal radioactivity。

2. The localities where chalcopyrite has been identified have the greatest percentage of significant abnormal radioactivity.

3. Approximately the same percentage of localities where chalcopyrite plus pyrite were identified and where galena -sphalerite plus chalcopyrite were identified have significant abnormal radioactivity.

Table $2_{0}$ - Relation of significant abnormal radioactivity and vein mineralogy。

Vein type. significant abnormal radioactivity

Pyritic

$$
3.4
$$

Galena-sphalerite

15.5

Chalcopyrite with both pyrite and galena-sphalerite

24.0

Chalcopyrite with pyrite

21.0

Chalcopyrite with galena-sphalerite

24.7

- For purposes of calculations for these tables, the assumption was made that localities showing only limonite belonged to the vein type of the geographic area in which they occur. 
Table $3{ }^{-}$- Relation of significant abnormal radioactivity to mineral zones. with significant abnormal radioactivity

Pyritic type veins

Galena-sphalerite veins

Chalcopyrite with galena-sphalerite veins

Area of galena-sphalerite type veins with or without chalcopyrite (zones not delimited)
6.3

22,9

$22_{\mathrm{o}} 1$

10.1

The data in table 3 are based upon the zones as outlined in figure 3 without regard for the mineralogy at any particular locality. The percentage of the localities with significant abnormal radioactivity in the pyritic zone is lower than that for the remainder of the area studied。 Of the 8 localities within the pyritic zone showing significant abnormal radioactivity, 3 have chalcopyrite with the pyrite. The lack of significant abnormal radioactivity in the central part of the pyritic zone is further emphasized by the observation that 6 of these 8 localities are near the margin and no localities with high and only one with moderate abnormal radioactivity occur within this zone.

When the data are considered from either of the two viewpoints (the localities individually or the distribution in mineral zones $\%_{0}$ similar conclusions are reached. Localities that have the pyritic type of vein without chalcopyrite are poor prospects for radioactive materials. Only the margin of the pyritic zone is favorable for localities showing significant abnormal radioactivity。 The localities containing chalcopyrite have the highest grade as well as the highest percent of occurrence of significant abnotmal radioactivity. Five of the seven localities with high abnormal radioactivity contain chalcopyrite. The other two localities have galena-sphalerite type veins. No locality with a pyritic type vein has high or moderate abnormal radioactivity. If the presence of chalcopyrite defines the intermediate zone between the pyritic and galena-sphalerite types of veins, then the intermediate zone $e_{0}$ as suggested by Leonard (1952), appears to be the most fayorable area for pitchblende prospecting in this part of the Front Range. 
Econom ic significance

In the region covered by this report only the 7 localities showing high abnormal radioactivity contain uranium of ore grade at present prices, These 7 localities are considered to contain possible ore deposits and, therefore, are worthy of at least some exploration。 As of March 1953, the Golconda and Martha E mines were being explored, but no uranium ore had yet been shipped. The owners of the Almaden,

Golden Calf, and Diamond Mountain mines are considering exploration, No information is available as to the possibilities of exploration in the Orinoco mine and the Baltic tunnel。

A more objective evaluation of the potentialities of uranium production from this region awaits the results of detailed studies of the uranium occurrences Additional information from producing mines is necessary to determine what economic significance can be attached to various amounts of abnormal radioactivity and to the pattern of its distribution.

\section{LITERATURE CITED}

Bastin, E. S 。 and Hill, J。 $M_{0}, 1917$. Economic geology of Gilpin County and adjacent parts of Clear Creek and Boulder Counties, Colorado: U. S。 Geol. Survey Prof, Paper 94.

Brownell, G. M. 1950, Radiation surveys with a scintillation counter: Econ。 Geol., vo 45, p. 167-174.

Korff, S. A, 1946 , Electron and nuclear counters: D。 Van Norstrand Co. Inc ${ }_{0}$, New York。

Leonard, $B_{0} F_{0}, 1952$, Relation of pitchblende deposits to hypogene zoning in the Front Range mineral belt. Colorado: Geol。 Soc. America Bull., v。 63, no, 12, pt, 2, p。 1274-1275 (abs.).

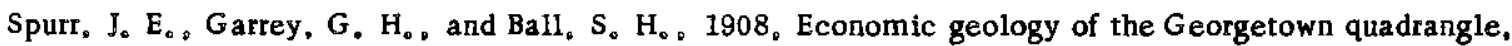
Colorado: U. S。 Geol。 Survey Prof ${ }_{\mathrm{o}}$ Paper 63,

\section{UNPUBLISHED REPORTS}

Harrison $I_{0} E_{0}, 1952$, The uranium occurrences in the Martha E prospect, near Idaho Springs, Colorado: U. S. Geol. Survey Trace Elements Memo. Rept。291.

Phair George, 1952, Radioactive Tertiary porphyries in the Central City district, Colorado, and their bearing upon pitchblende deposition: $U_{0} S_{0}$ Geol. Survey Trace Elements Inv。 Rept。247. (Open-filed by $U_{0}$ S. Atomic Energy Comm. Tech. Inf, Service, Oak Ridge, Tenn。). 
UNPUBLISHED REPORTS- - Continued

Phair, George, and Levine, Harry, 1952, Notes on the differential leaching of uranium, radium, and

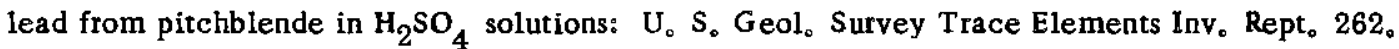
(Open-filed by $U_{0}$ S. Atomic Energy Commo Tech, Inf $_{0}$ Service, Oak Ridge, Tenn $)_{\circ}$

Sims, $P_{0} K_{0}$, Harrison, $J_{0} E_{0}$ and Moore, $F_{0} B_{0}, 1953$, Preliminary report on 1952 investigations in the Colorado Front Range: U. S。 Geol. Survey Trace Elements Memo Rept $_{0} 520$ 。

Smith, $L_{0} E_{0}$ and Baker, K, E。 1951, Uranium in Fall River area, Clear Creek County, Colorado: U. S. Atomic Energy Comm. RMO-913。

1952, U. S A A tomic Energy Comm. PRR-DEB-RR-446. 
FIG. 2 - MAP OF NORTH-CENTRAL CLEAR CREEK COUNTY, COLORADO, SHOWING RADIOACTIVITY OF LOCALITIES EXAMINED. 


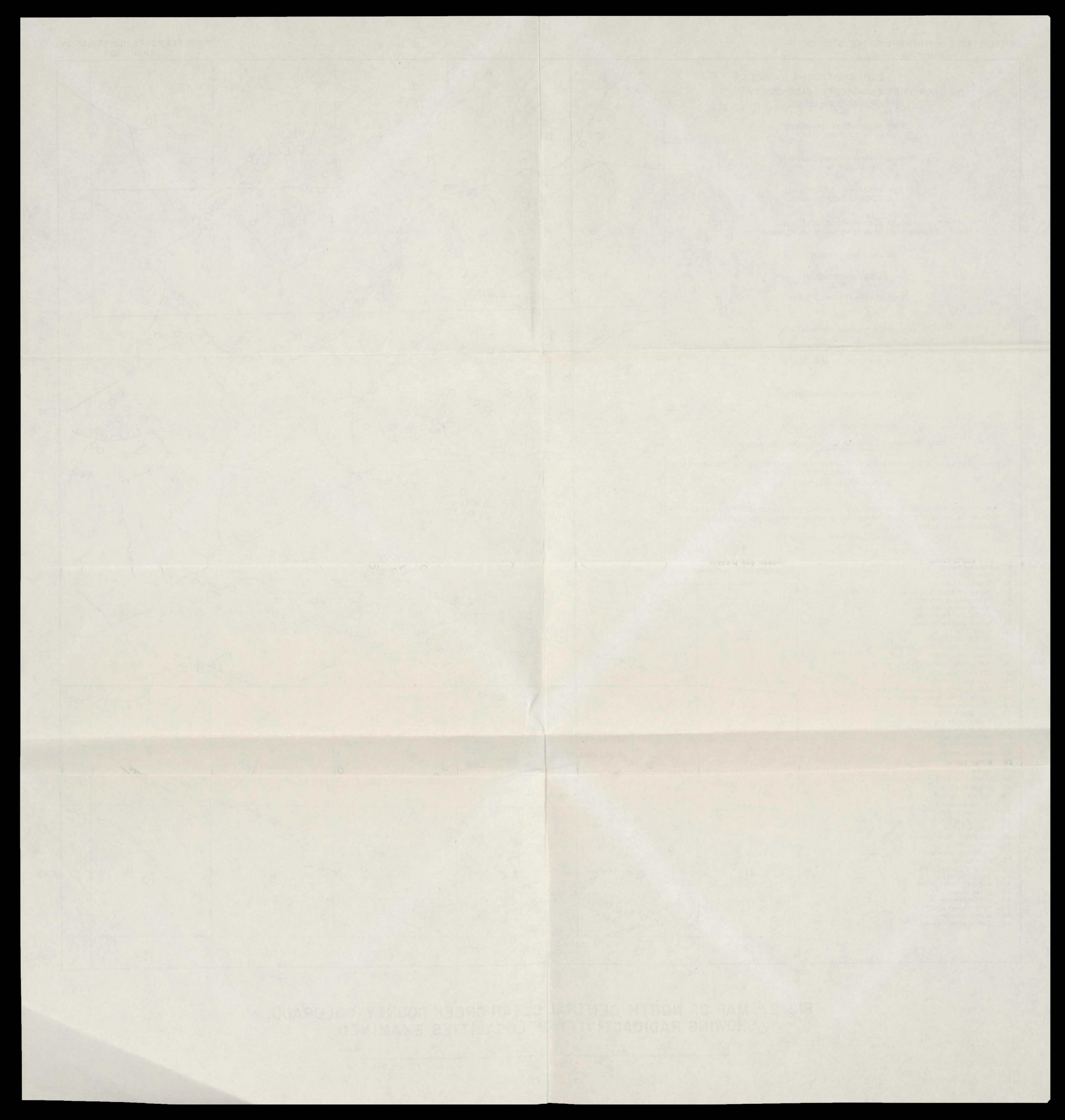




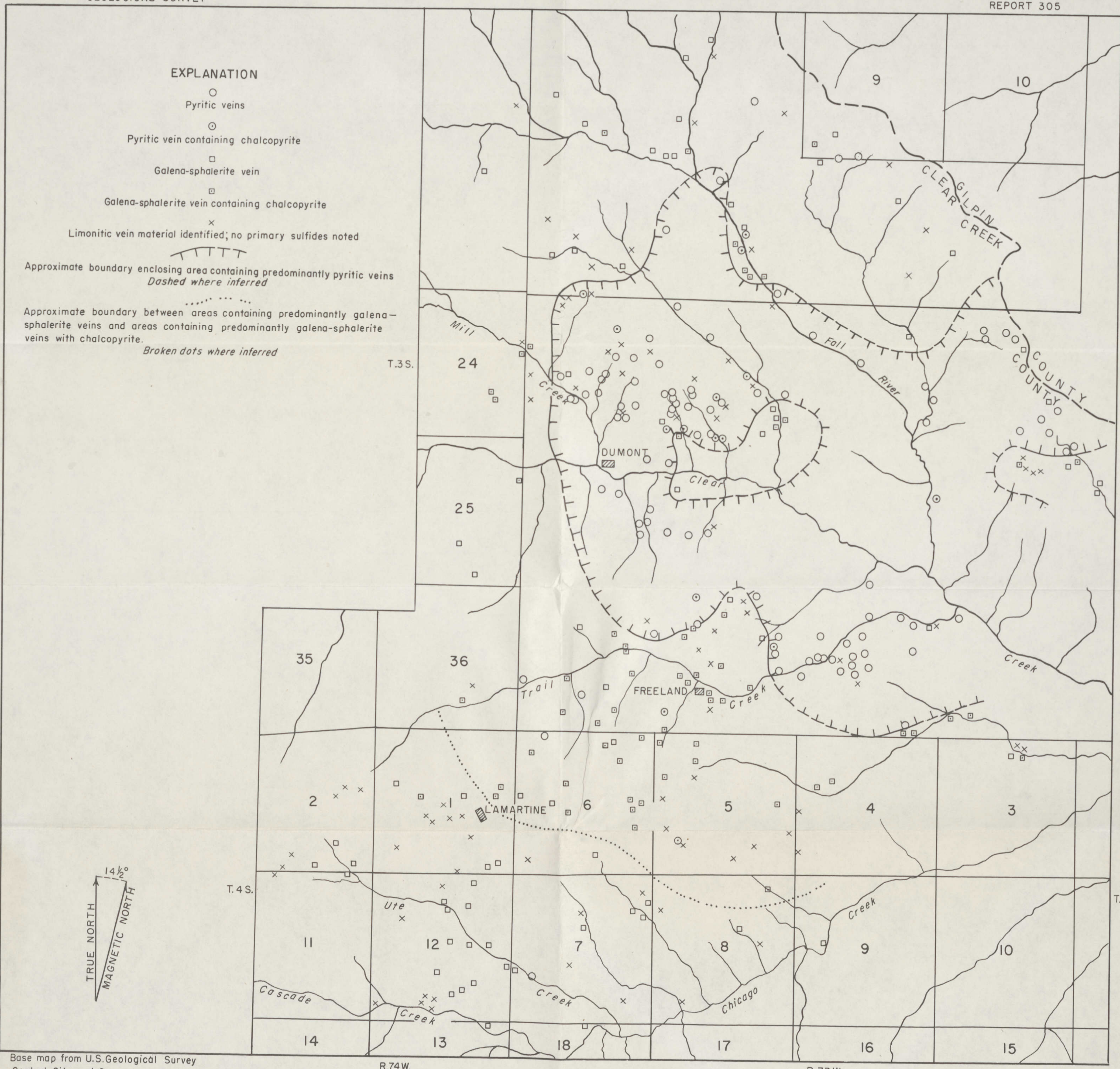

FIGURE 3-MAP OF PART OF NORTH-CENTRAL CLEAR CREEK COUNTY, COLORADO, SHOWING DISTRIBUTION OF VEIN TYPES. 


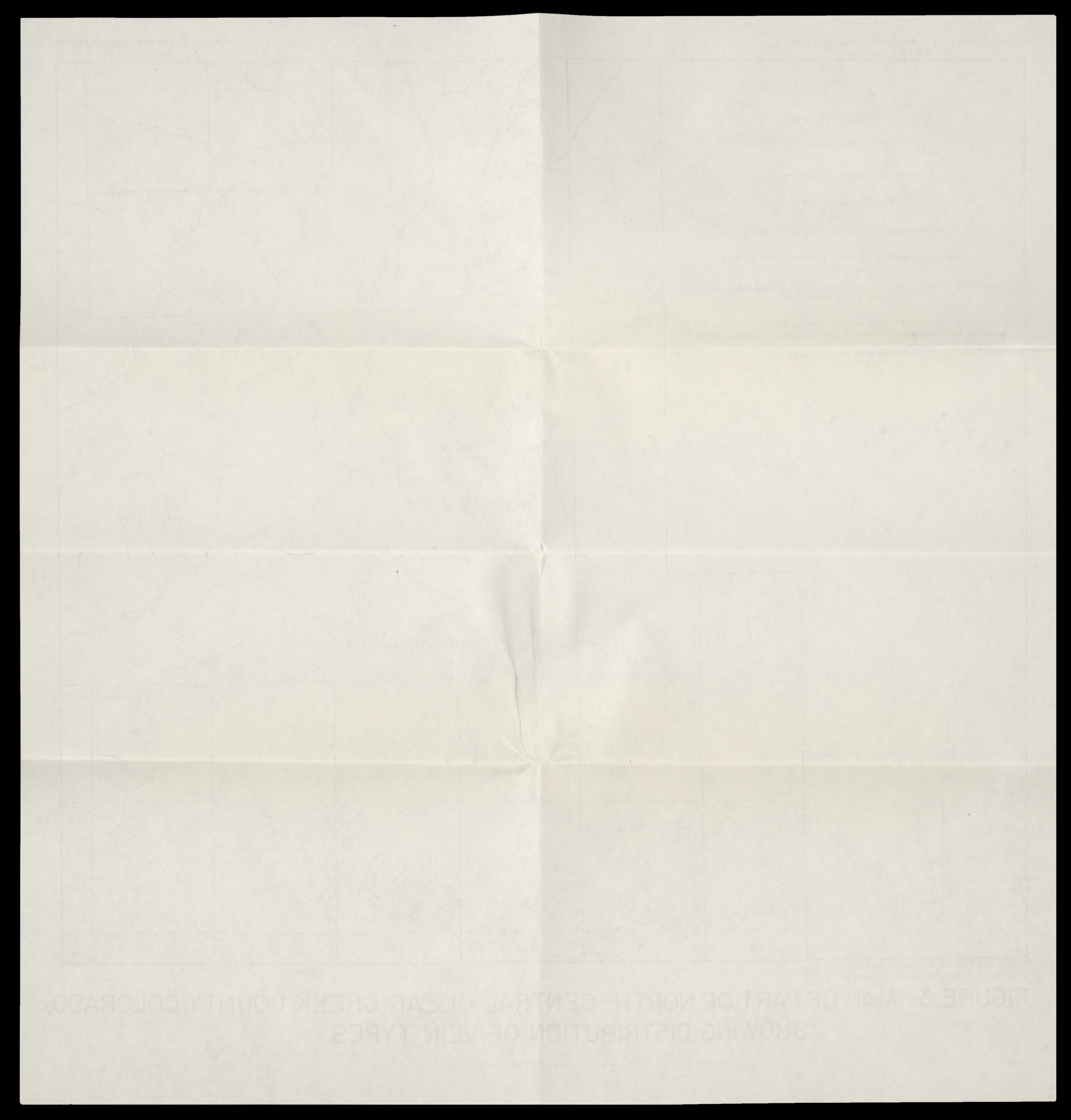


